\title{
Carbon isotope field study of shale gas and tight gas in China
}

\author{
Di ZHU1, RANRAN LiU2, HUANXU ZHANG 3
}

1 Key Laboratory for biomass Gasification Technology of Shandong Province, Energy Research Institute, Qilu

University of Technology (Shandong Academy of Sciences), Jinan, 250014, China (*cprrespondence: zhud@sderi.cn)

2 Institute of Atmospheric Physics, Chinese Academy of Sciences, Beijing, 100029, China

(liuranran@mail.iap.ac.cn)

3 Power and environmental energy research institute, Covina, 91722, CA, USA (huanxu_zhang@sina.com)

The stable carbon isotopes field study has been increasingly applied in Chinese oil and gas plays. Here we demonstrate two cases which were accomplished in 2019 using an isotopic analyser developed by Power and environmental energy research institute and Chinese Academy of Sciences. The first case focused on studying at two sets of ancient shale series of strata in Niutitang and Doushantuo formations drilled in Well Eyangye-2, and the second focused on studying the charging characteristics of the northern slope of Minfeng subsag in Bohai Bay Basin.

In both cases, continuous sampling while drilling was conducted in the well site; the changes of the carbon isotope values of mud gas and the carbon isotope values of cuttings head space gas with time series were measured. Carbon isotopic data, together with gas content, formation lithology and other mud logging results, threw light on determining the sweet spot of shale gas. Especially, the carbon isotope fractionation characteristics of the gas released from cuttings reveals the development degree of nanopore in shale, which then largely corresponds to the geologic sweet spot in shale gas reservoirs. It's practical to use the development degree of nano pore-throat system as the judgment index of sweet spot in shale gas. Besides, the results show that the reversal characteristics and humidity characteristics of methane and ethane indicate that Niutitang Formation may have good potential for shale gas exploration. The variation of carbon isotope value of mud gas with true vertical depth (TVD) is related to the residual liquid hydrocarbons in the oil generation window. The light isotope at the bottom of the Niutitang Formation shale reveals that there are large quantities of residual liquid hydrocarbons, showing great resource potential. The dry component and heavy carbon isotope of the Doushantuo Formation shale gas may have certain relation with the hydrocarbon generation. 